\title{
Cointegration and Causality between Stock Prices and Exchange Rate: Empirical Evidence from India
}

\author{
D. Bhuvaneshwari ${ }^{1 *}$ and K. Ramya ${ }^{2}$ \\ 'Research Scholar, Avinashilingam School of Management Technology, Avinashilingam Institute for Home \\ Science and Higher Education for Women, Coimbatore, India \\ ${ }^{2}$ Assistant Professor (SS), Avinashilingam School of Management Technology, Avinashilingam Institute for \\ Home Science and Higher Education for Women, Coimbatore, India
}

\begin{abstract}
Predicting the exchange rate fluctuations and volatility is possibly one of the very toughest exercises in economics as it affects the market movement. The dynamic relationship between stock prices and exchange rate have drawn the attention of many economists for both theoretical and empirical reasons and plays an important role in influencing the development of a country's economy (Nieh \& Lee, 2001). Therefore, the present study is focusing on stock market prices and exchange rate, which in theory, is expected that one affects the other. The US Dollar (USD)-Indian Rupee (INR) exchange rates and stock market prices of India from January 2006 to December 2015 are considered as sample data for this study. In this research, Augmented Dickey-Fuller (ADF) and Phillips-Perron (PP) unit root tests are applied to test stationarity of data and the data was found stationary at first difference. Karl Pearson correlation test was used to find the correlating relationship between the variables and it is found that both the variables are significantly correlated. Johansen's cointegration test is applied to determine the long-run equilibrium relationship between the study variables and identified that the variables are not cointegrated. Granger causality test is employed to determine the causality and short-run relationship between the variables and the result revealed bidirectional causality between variables.
\end{abstract}

Keywords: Exchange Rates, Stock Prices, Unit Root Tests, Karl's Pearson Correlation Test, Johansen Cointegration Test, Granger Causality Test

\section{Introduction}

Many macroeconomic indicators like Gross Domestic Product (GDP), inflation, stock prices, interest rates, fiscal policies, etc. are said to have an impact on the foreign exchange rates. Exchange rate has become one of the most essential determinants of a country's relative economic health, especially with the increase in the world trade, capital and stock price movements (Sinha \& Kohli, 2015). An exchange rate between two currencies is the rate at which one currency will be exchanged for another currency. In India, USD is considered as the primary exchange currency rate for
Indian rupee. According to Azman-Saini, Habibullah and Law (2006) and Stavarek (2004) mutual relationship between foreign currency exchange rate and the stock market prices have attracted much attention of researchers and academics since the beginning of 1990s. The relationships between stock market prices and exchange rate are studied systematically by financial economists and have frequently been utilised in forecasting the future values of exchange rates and stock prices by fundamentalists and investors.

Many domestic and foreign investors become nervous about the current state of the Indian economy due to

*Email: 14.bhuvi@gmail.com 
the possible reasons of depreciation of the INR which includes problems of high fiscal deficit, lack of reforms, global uncertainties, fluctuations in commodity market prices, etc. Around 2009 and 2010, the exchange rate was wavering between INR43 and INR45 per US Dollar (Singhal, 2012). During 2014-2015, the exchange rate was around 60-67 rupees per US dollar. High volatility in India's exchange rate value affects the stock prices of Indian stock markets and vice versa. Under traditional approach assumption, exchange rate leads the stock prices. Whereas, the assumption of portfolio approach is that the stock prices leads exchange rate. There are numerous literatures with difference of opinion and results. For instance, Tabak (2006) concluded that stock prices led exchange rate with negative relationship. Stavarek (2004) reported unidirectional causality running from stock market prices to exchange rate. The study by Granger, Huang and Yang (2000) concluded that exchange rate led stock prices in South Korea. Ong and Izan (1999) reported insignificant relationship between equity prices and foreign exchange rate by examining the relationship between spot and 90 day forward exchange rates for G7 countries and Australia. Therefore, the present study is aimed at analysing the impact and relationship between USD-INR exchange rate and Indian stock prices during the period 2006-2015.

\section{Review of Literature}

The following are the literature reviews that demonstrated the relationships between stock prices and exchange rate.

The results of the international studies relating to stock prices and exchange rate are as follows. Zhao (2010) used monthly data of stock prices and exchange rate from January 1991-2009 and analyzed the dynamic relationship between Renminbi (RMB) exchange rates and stock prices by using VAR and multivariate GARCH models. The study concluded that the stock market had a great effect on future volatility in foreign exchange market. Kutty (2010) examined the short and long-run relationship between exchange rate and stock prices in Mexico during 1989-2006 with Granger causality test. The study found that stock market prices led exchange rates in the short-run, and showed that there was no long-run relationship between both time series. The study by Abdalla et al; (2010) also investigated the relationship between stock market prices and exchange rate in Korea, Pakistan and the Philippines with Bivariate Vector Autoregressive Model (BVAM) using monthly observations from January 1985 to July 1994 and found unidirectional causality from exchange rate to stock market prices in all the selected countries, except for the Philippines.

The study by Rahman et al; (2009) examined the interactions between stock prices and exchange rate in Bangladesh and Pakistan. The study considered average monthly exchange rate of USD in terms of Taka (Bangladesh Currency) and Pakistani Rupee and monthly stock prices of DSE, BSE and KSE respectively from January 2003-June 2008 and found that there was no causal relationship and long-run relationship between exchange rate and stock prices in the countries. Pan et al; (2007) studied relationship between stock prices and exchange rate for seven East Asian countries from January 1988-October 1998. By using Granger causality tests, Variance Decomposition Method (VDM) and Impulse Response Function (IRF), the causal relation was found from exchange rate to stock prices for Hong Kong, Japan, Malaysia, and Thailand and from stock prices to the foreign exchange rate for Hong Kong, Korea, and Singapore before the 1997 Asian financial crisis and found causal relation from exchange rate to stock prices for all the sample countries except Malaysia during the Asian crisis.

Yau et al; (2006) found the short-run and long-run inter relationships among the stock prices of Japan and Taiwan and Yen/NTD exchange rate respectively during January 1991-July 2005 by employing various linear, non-linear and time-series methodologies. The study resulted that there was short-run relationship and no long-run relationship was found between the time series. The study by Phylaktis \& Ravazzolo (2005) also investigated dynamics between exchange rate and stock prices for Pacific Basin countries during 1980-1998 by using Johansen's cointegration test and multivariate Granger causality tests. The evidence suggested that exchange and stock prices were positively related and found that the financial crisis had an 
interim effect on the long-run co-movement of these markets. Kim (2003) studied the existence of long-run equilibrium relationships among the stock prices and exchange rate in the US during 1974-1998. This study applied Johansen's cointegration analysis and found that the S\&P 500 stock prices were negatively related to the real exchange rate.

Muhammad et al; (2002) examined the short-run and long-run associations between stock prices and exchange rate for Pakistan, Bangladesh and Sri Lanka during 1994-2000. The researchers applied cointegration, error correction modelling approach, and standard Granger causality tests. The study identified no short-run association between time series data for Bangladesh and Sri Lanka but a bi-directional long-run causality was found between the variables and there were no short-run and long-run associations between stock prices and exchange rate for Pakistan. Nieh et al; (2001) empirically found that there was no longrun significant relationship between stock prices and exchange rate in the G-7 countries during 1993-1996 by using time series estimations. The study by Granger, et al; (2000) employed unit root test and cointegration models to determine the appropriate causal relationship between exchange rate and stock market prices using recent Asian flu data during January 1986 June 1998. The study found that the data from South Korea were in agreement with the traditional approach (exchange rates led stock prices) and also identified that the data of the Philippines suggested the result expected under the portfolio approach (stock prices led exchange rate) with negative correlation. Data from Hong Kong, Malaysia, Singapore, Thailand, and Taiwan indicated strong feedback relations, whereas Japan and Indonesia failed to reveal any recognizable causality pattern.

The following are the Indian studies that examined the relationship between foreign exchange rate and stock market prices. Sinha et al; (2015) studied the effect of exchange rate from the period January 2006-March 2012 on BSE Sensex index, BSE Oil \& Gas sector index and BSE IT sector index by using least square regression model and found negative and insignificant interactions between foreign exchange rate and stock returns. Basher, Haug \& Sadorsky (2012) used structural vector auto regression model to investigate the relationship between exchange rate and stock prices. The study finally concluded that the increase in oil prices led to decrease in emerging stock market prices and that had resulted with an increase in foreign exchange rate. Studies by Agrawal, et al; (2010) and Abdalla et al; (2010) for the period October 2007-March 2009 and January 1985-July 1994 respectively resulted with negative and unidirectional relationship between foreign exchange rate and stock market prices using Granger causality test and Bivariate Vector Autoregressive Model (BVAM).

Rahman et al; (2009) examined the interactions between BSE stock prices and exchange rates during January 2003-June 2008 by using Granger causality test and found that there was no causal relationship between stock prices and exchange rate. Nath et al; (2003) also examined the dynamic linkages between the stock market prices and foreign exchange rate with Granger causality test for the period from March 1993 to November 1995. The study showed that returns of stock market and foreign exchange rate were not inter-related and pointed out that the stock market returns have causal influence exchange rate returns with possibility of mild influence in reverse direction. A study by Muhammad et al; (2002) for the period 1994-2000 concluded that there were no shortrun and long-run causal relationships or associations between stock market prices and foreign exchange rate. Granger, et al; (2000) examined the relationship between stock prices and exchange rate during January 1986-June 1998 and found that stock market prices of India and exchange rate had not revealed any recognizable pattern of causality between those time series.

\section{Statement of the Problem, Objectives and Hypotheses}

\subsection{Statement of the Problem}

In an open economy, the expectations of relative currency values influence the levels of domestic and foreign interest rates which in turn affect the present value of 
firms' assets. This suggested that exchange rate plays a considerable role in the movements of stock prices (Nieh \& Lee, 2001). Investors can make investment decisions only when they are know about the price volatility of market indicators but most of the investors have confusions regarding the influence/cause of one indicator on the other. Finding the relationship between stock prices and exchange rate may help the researchers, fundamentalist and investors to predict the trend of Indian stock market. Because, investors and fundamentalists believe that there is a relationship between these two variables which in return lead to the changes or fluctuations in each other. This makes the investors to think about the cause and effect due to the changes and the fluctuations.

In this background, the study has raised the following research questions:

- Does the stock prices and exchange rate data are predictable?

- Do stock prices and exchange rate have any correlating relationship between each other?

- Does long-run equilibrium exists between stock prices and exchange rates?

- Is there any causal relationship exists between stock prices and exchange rate?

\subsection{Objective}

- To find the relationship between Indian stock prices and exchange rate

\subsection{Hypotheses}

The following hypotheses are set to beempirically tested to study the above mentioned objective:

- $\mathbf{H}_{1}$ : The study variables stock prices and exchange rate are not normally distributed.

- $\mathbf{H}_{2}$ : Unit root exists (i.e., non stationarity) in the study variables.

- $\mathbf{H}_{3}$ : There is no structural break in the study variables.

- $\mathbf{H}_{4}$ : There is no long-run equilibrium between the study variables.

- $\mathbf{H}_{5}$ : There is no causality existing between stock prices and exchange rate.
- $\mathbf{H}_{5 \mathrm{a}}$ : Stock prices does not Granger cause exchange rate.

- $\mathbf{H}_{5 b}$ : Exchange rate does not Granger cause stock prices.

\section{Data and Methodology}

The data for exchange rate and stock market prices are collected from secondary sources. The period of this study is from January 2006 to December 2015. S\&P CNX Nifty of NSE has been considered for the study because it is an index constructed with impact cost consideration and it is one of the most robust indices available for Indian stock market. The stock prices of S\&P CNX Nifty were downloaded from the NSE website. The INR exchange rate per 1 USD for the period from January 2006 to December 2015 was taken from the website of Reserve Bank of India (RBI) - Database on Indian Economy (DBIE).

In this study, the following are the econometric and statistical tools used for analysing the data.

\section{Analysis and Interpretation}

\subsection{Descriptive Statistics}

The descriptive statistics of the study variables are presented in Table 2. The table shows that there is a large difference between the minimum and maximum values of the study variables. It also indicates that there is wide fluctuation in the movement of study variables and their index points and prices have grown rapidly during the study period.

The skewness is positive for both the study variables which indicate that the upper tail of the distribution is thicker than the lower tail. This implies that the study variables do not decline more often. It further suggests that the study variables are exhibiting rational and systematic returns. The kurtosis coefficient values ofstock prices and exchange rate is positive and found to be less than 3 , which indicates that the distribution to be platykurtic with fewer and less extreme outliers. Subsequently, the Jarque-Bera test statistics suggest that all variables are non-normally distributed. Thus, Hypothesis 1 is accepted and inferred that stock 
Table 1.

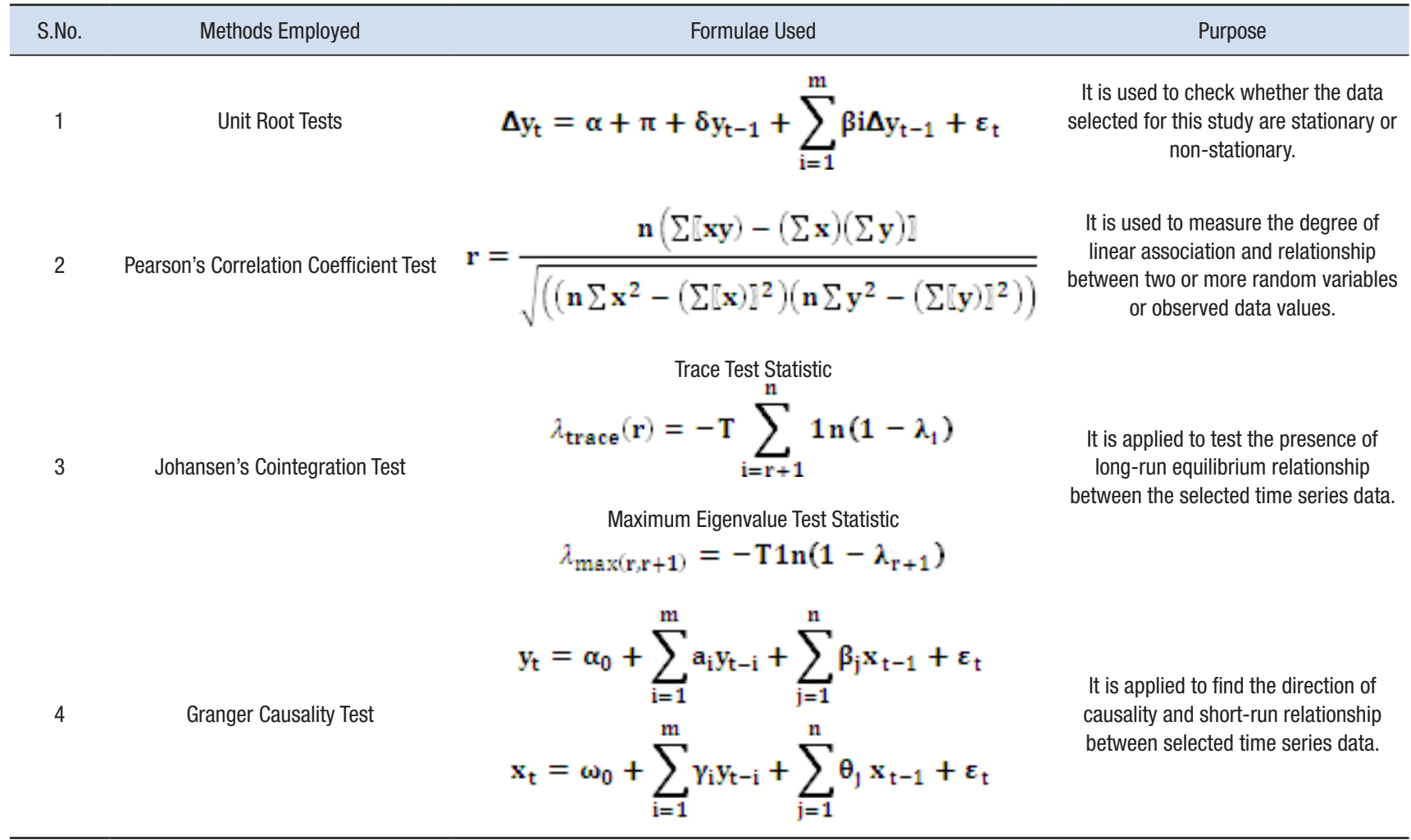

Table 2. Descriptive statistics of stock prices and exchange rate

\begin{tabular}{ccc}
\hline Particulars & Stock Prices & Exchange Rate \\
\hline Mean & 5403.969 & 50.81809 \\
Median & 5296.620 & 48.45860 \\
Maximum & 8750.440 & 66.59550 \\
Minimum & 2802.270 & 39.37370 \\
Standard Deviation & 1537.728 & 7.907095 \\
Skewness & 0.43 & 0.48 \\
Kurtosis & 2.67 & 1.92 \\
Jarque-Bera & 11.28 & 10.52 \\
Probability & 0.00 & 0.00 \\
Observations & 120 & 120 \\
\hline
\end{tabular}

prices and exchange rate are not normally distributed. The results are found to be in line with the results of Kumari \& Mahakud (2015).

\subsection{Testing the Data for Stationarity}

The results for the ADF and PP unit root test for checking stationarity of the data are presented in Table 3.
Table 3. Results of ADF and PP unit root tests

\begin{tabular}{ccccc}
\hline $\begin{array}{c}\text { Time Series } \\
\text { Data }\end{array}$ & \multicolumn{2}{c}{ ADF Unit Root Test } & \multicolumn{2}{c}{ PP Unit Root Test } \\
& Level & $\begin{array}{c}\text { First } \\
\text { Difference }\end{array}$ & Level & $\begin{array}{c}\text { First } \\
\text { Difference }\end{array}$ \\
\hline $\begin{array}{c}\text { Stock Prices } \\
\begin{array}{c}\text { Exchange } \\
\text { Rate }\end{array}\end{array}$ & -2.44 & $-8.81^{* *}$ & -2.45 & $-8.82^{\star *}$ \\
\hline
\end{tabular}

** Significant at $1 \%$ level

From the above table, it is identified that stock prices and exchange rate are found to be non-stationary series at level form but found to be stationary at first difference. Hence, both the data are statistically significant and integrated at order I(1). Therefore, the hypothesis 2 is rejected and it is understood that the sample data taken for this study are stationary i.e. predictable. The result of this study was found to be parallel with the results of Sinha et al; (2015) and Nieh et al; (2001).

The generated graphical representations of the first differenced stationary time series data are as follows. 


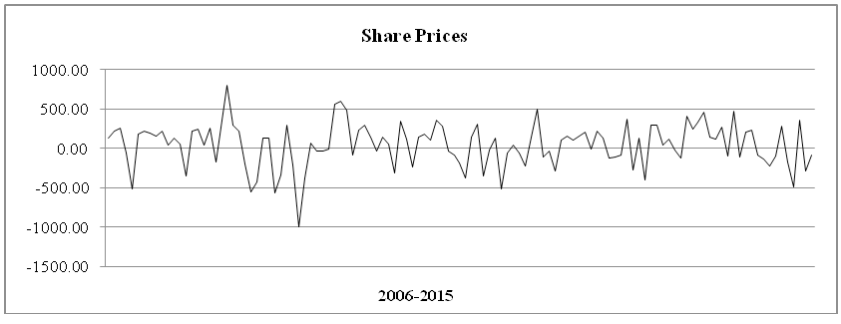

Figure 1. Line Chart for Stock PricesI(1).

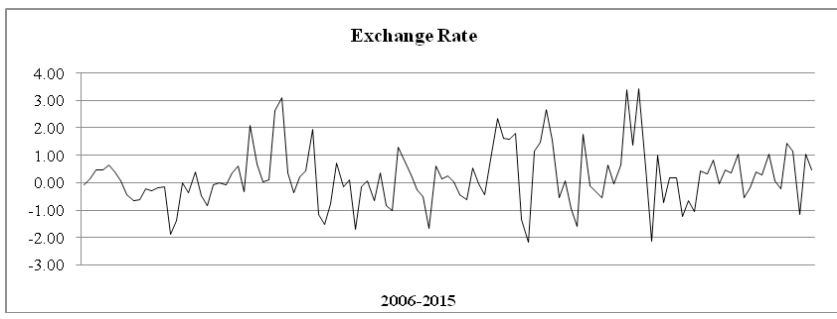

Figure 2. Line Chart for Exchange RateI(1).

\subsection{Testing the Relationship between the Study Variables}

To find the linear relationship between the study variables Karl Pearson's correlation test is applied. The result of correlation test is presented in Table 4.

The relationship between the study variables is found to be positively correlated and significant at the 0.01 level. Average correlation (70\%) is found between stock prices and exchange rate. Therefore, it is inferred that there is significant linear relationship between both the variables.

\subsection{Testing of Structural Breaks}

Chow breakpoint test is used for determining the presence of any structural breaks in the movement of variables during the period 2008-2009. The period 2008-2009 is selected to determine the structural breaks because of the financial crises happened during that period.
The Chow test results shows that the $\mathrm{P}$ value is insignificant i.e. ( $\mathrm{P}>0.05)$. Therefore, Hypothesis 3 is accepted which means that there is no structural breaks inboth the time seriesduring the period 2008-2009.

\subsection{Testing for Existence of Long-Run Equilibrium Relationship}

Johansen's cointegration test is applied to find stationary linear combination and long-run cointegrating equilibrium among the non-stationary variables. This test was introduced by Johansen (1988) and Johansen \& Juselius (1991). The results of trace test and maximum eigenvalue test are presented in the table 5.5.

Results clearly reveal that both trace test value and maximum eigenvalue test value is less that $5 \%$ critical value. Hence both the test values are found insignificant i.e., $\mathrm{P}>0.05$. Therefore, Hypothesis 4 is acceptedwhich means that there is no long-term co-movement between stock prices and exchange rates and none of the variables is predictable on the basis of past values of other variable. The result of this analysis is in line with the results of Rahman \& Uddin (2009) and contradictory with the results of Yau \& Nieh (2006).

Table 4. Results of correlation coefficient test

\begin{tabular}{|c|c|c|c|}
\hline \multicolumn{2}{|c|}{ Particulars } & Stock Prices & Exchange Rate \\
\hline \multirow{2}{*}{ Stock Prices } & $\begin{array}{l}\text { Pearson } \\
\text { Correlation }\end{array}$ & 1 & $0.699^{\star *}$ \\
\hline & $\begin{array}{c}\text { Significance } \\
\text { (2-tailed) }\end{array}$ & & 0.000 \\
\hline
\end{tabular}

** Correlation is significant at the 0.01 level (2 tailed)

Table 5. Results of chow test for testing structural breaks

\begin{tabular}{cccc}
\hline \multicolumn{1}{c}{ Variables } & $\begin{array}{c}\text { Breakpoint } \\
\text { Period }\end{array}$ & FValue & PValue \\
\hline $\begin{array}{c}\text { Exchange Rate } \\
\rightarrow \text { Stock Prices }\end{array}$ & $2008-2009$ & 0.97 & 0.43 \\
\hline
\end{tabular}

Table 6. Results of Johansen's cointegration test

\begin{tabular}{cccccccc}
\hline Variables & $\mathrm{H}_{0}$ & Trace Test & $5 \%$ Critical Value & PValue & Maximum Eigenvalue Test & $5 \%$ Critical Value & PValue \\
\hline Stock Prices and & $\mathrm{r}=0$ & 11.52 & 15.49 & 0.18 & 9.36 & 14.26 & 0.26 \\
Exchange Rate & $\mathrm{r} \leq 1$ & 2.16 & 3.84 & 0.14 & 2.16 & 3.84 & 0.14 \\
\hline
\end{tabular}

Note: 1 to 4 is taken as lag length for first difference of time series data MacKinnon-Haug-Michelis (1999) estimated probability values 
Table 7. Results of Granger causality test

\begin{tabular}{cccc}
\hline Null Hypotheses & FValue & PValue & Results \\
\hline $\begin{array}{c}\text { Stock prices does not } \\
\text { Granger cause exchange } \\
\text { rate }\end{array}$ & 2.76 & $0.02^{*}$ & $\begin{array}{c}\text { Reject } \\
\text { hypothesis 5a }\end{array}$ \\
$\begin{array}{c}\text { Exchange rate does not } \\
\text { Granger cause stock prices }\end{array}$ & 2.26 & $0.05^{*}$ & $\begin{array}{c}\text { Reject } \\
\text { hypothesis 5b }\end{array}$ \\
\hline * Significant at the 0.05 level & & &
\end{tabular}

\subsection{Testing for Causality}

Granger causality test is used in this study to determine the causality between the study variables i.e. to check whether one variable is useful in forecasting the other variable and also helps in determining the short-run equilibrium relationship. For instance: variable X might 'Granger cause' variable Y if past values of variable X explain variable Y. Similarly, variable Y 'Granger causes' variable $X$, if past values of variable $Y$ explain variable $X$. The results of Granger causality test are presented in Table 5.6.

The results indicate that there is causality between the study variables. The direction of causality is found to be bidirectional (from stock prices $\rightarrow$ exchange rate and also from exchange rate $\rightarrow$ stock prices) and significant at 5\% level. Therefore, Hypothesis 5 is rejected. The result of this analysis was found parallel to the studies by Granger et al. (2000) and BahmaniOskooee \& Sohrabian (1992) and is contradictory to the results of Kutty (2010), Pan et al. (2007) and Ajayi \& Mougoue (1996).

\section{Conclusion}

The study examined the cointegrating and causal relationship between Indian stock prices and exchange rate by using the monthly data for the period January 2006December 2015. The data series of the study variables was non-stationary and became stationary series at first difference. Hence, all the study variables are integrated at order I(1). Karl Pearson's correlation test resulted with statistically significant and positive relationship between all the study variables. Johansen cointegration test exhibited the absence of long-run relationship between stock prices and exchange rate. That means there is no longterm co-movement between the variables and none of the variables is predictable on the basis of past values of other variable. In the absence of any cointegrating relationship between the variables, Granger causality test is applied to find out any causal and short-run relationship between stock prices and exchange rate. Granger causality test resulted with bidirectional causality i.e. causality running from Indian stock prices to INR/USD exchange rate and vice versa. Therefore, it is concluded that this study supports McKinnon's (1973) “Complementarity Hypothesis". In this study, variables do not cointegrate at the long-run period but the relationship and causality between the variables in the short-run are highly significant. There is a common belief among the investors that there is an association between stock prices and exchange rate and they are predictable on the basis of the values of other variables. But based on the causal relationship without any long-term cointegrating relationship, it is very difficult for the market participants to improve the forecast of other market.

\section{References}

Abdalla, I. S., \& Murinde, V. (1997). Exchange rate and stock price interactions in emerging financial markets: evidence on India, Korea, Pakistan and the Philippines. Applied financial economics, 7(1), 25-35. Retrieved From: https://doi.org/10.1080/096031097333826

Agrawal, G., Srivastav, A. K., \& Srivastava, A. (2010). A study of exchange rates movement and stock market volatility. International Journal of Business and Management, 5(12), 62-73. Retrieved From: https://doi.org/10.5539/ ijbm.v5n12p62

Ajayi, R. A., \&Mougoue, M. (1996). On the dynamic relation between stock prices and exchange rates. Journal of Financial Research, 19(2), 193-207. Retrieved From: https://doi.org/10.1111/j.1475-6803.1996.tb00593.x

Azman-Saini, W. N. W., Habibullah, M. S., Law, S. H., \& Dayang-Afizzah, A. M. (2006). Stock prices, exchange rates and causality in Malaysia: A note. Munich Personal RePEc Archive, 653(3), 1-15.

Bahmani-Oskooee, M., \& Sohrabian, A. (1992). Stock prices and the effective exchange rate of the dollar. Applied economics, 24(4), 459-464. Retrieved From: https://doi. org/10.1080/00036849200000020

Basher, S. A., Haug, A. A., \& Sadorsky, P. (2012). Oil prices, exchange rates and emerging stock markets. Energy Economics, 34(1), 227-240.Retrieved From: https://doi. org/10.1016/j.eneco.2011.10.005 
Granger, C. W., Huang, B. N., \& Yang, C. W. (2000). A bivariate causality between stock prices and exchange rates: evidence from recent Asianflu. The Quarterly Review of Economics and Finance, 40(3), 337-354. Retrieved From: https://doi.org/10.1016/S1062-9769(00)00042-9

Johansen, S., \& Juselius, K. (1990). Maximum likelihood estimation and inference on cointegration with applications to the demand for money. Oxford Bulletin of Economics and statistics, 52(2), 169-210. Retrieved from: https://doi.org/10.1111/j.1468-0084.1990.mp52002003.x

Kim, K. H. (2003). Dollar exchange rate and stock price: evidence from multivariate cointegration and error correction model. Review of Financial economics, 12(3), 301-313. Retrieved from: https://doi.org/10.1016/S10583300(03)00026-0

Kutty, G. (2010). The relationship between exchange rates and stock prices: the case of Mexico. North American Journal of Finance and Banking Research, 4(4), 1-12.

Muhammad, N., Rasheed, A., \& Husain, F. (2002). Stock prices and exchange rates: are they related? Evidence from South Asian countries. The Pakistan Development Review, 41(4), 535-550.

Nath, G. C., \&Samanta, G. P. (2003). Dynamic relation between exchange rate and stock prices: a case for India. In 39th Annual Conference paper of Indian Econometric Society also published in NSE News February.

Nieh, C. C., \& Lee, C. F. (2001). Dynamic relationship between stock prices and exchange rates for G-7 countries. The Quarterly Review of Economics and Finance, 41(4), 477-490. Retrieved from: https://doi.org/10.1016/ S1062-9769(01)00085-0

Ong, L. L., \& Izan, H. Y. (1999). Stocks and currencies: Are they related?.Applied Financial Economics, 9(5), 523-532. Retrieved from: https://doi.org/10.1080/096031099332186

Pan, M. S., Fok, R. C. W., \& Liu, Y. A. (2007). Dynamic linkages between exchange rates and stock prices: Evidence from East Asian markets. International Review of Economics \& Finance, 16(4), 503-520. Retrieved from: https://doi.org/10.1016/j.iref.2005.09.003

Patel, S. A. (2013). Causal relationship between stock market indices and gold price: Evidence from India. IUP Journal of Applied Finance, 19(1), 99-109.

Phylaktis, K., \& Ravazzolo, F. (2005). Stock prices and exchange rate dynamics. Journal of International Money and Finance, 24(7), 1031-1053. Retrieved from: https:// doi.org/10.1016/j.jimonfin.2005.08.001

Rahman, M. L., \& Uddin, J. (2009). Dynamic relationship between stock prices and exchange rates: evidence from three South Asian countries. International Business Research, 2(2), 167-174. Retrieved from: https://doi. org/10.5539/ibr.v2n2p167

Singhal, S. (2012). An Analytical Study on Indian Currency Rupee Depreciation against the US Dollar and Its Economic Impact. ArthPrabhand: A Journal of Economics and Management, 1(1), 74-83.

Sinha, P., \& Kohli, D. (2015). Modeling exchange rate dynamics in India using stock market indices and macroeconomic variables. Amity Global Business Review, 1(1), 5-18.

Stavarek, D. (2004). Linkages between stock prices and exchange rates in the EU and the United States. Czech Journal of Economics and Finance, 55(4), 141-161.

Tabak, B. M. (2006). The dynamic relationship between stock prices and exchange rates: Evidence for Brazil. International Journal of Theoretical and Applied Finance, 9(8), 1377-1396. Retrieved from: https://doi.org/10.1142/ S0219024906003974

Yau, H. Y., \& Nieh, C. C. (2006). Interrelationships among stock prices of Taiwan and Japan and NTD/ Yen exchange rate. Journal of Asian Economics, 17(3), 535-552. Retrieved from: https://doi.org/10.1016/j. asieco.2006.04.006

Zhao, H. (2010). Dynamic relationship between exchange rate and stock price: Evidence from China. Research in InternationalBusinessandFinance,24(2),103-112.Retrieved from: https://doi.org/10.1016/j.ribaf.2009.09.001

\section{Website References}

INR Exchange rate per 1 US dollar. In Database on Indian Economy. Available from: http://dbie.rbi.org.in/DBIE/ dbie.rbi?site=statistics

S\&P CNX Nifty closing stock prices.In NSE-National Stock Exchange of India Ltd. Available from: http:// www.nseindia.com/products/content/equities/indices/ historical_index_data.htm 